واكنش ارقام مختلف برنج (Oryza sativa L.) به سطوح مختلف شورى در شرايط آزمايشعاه

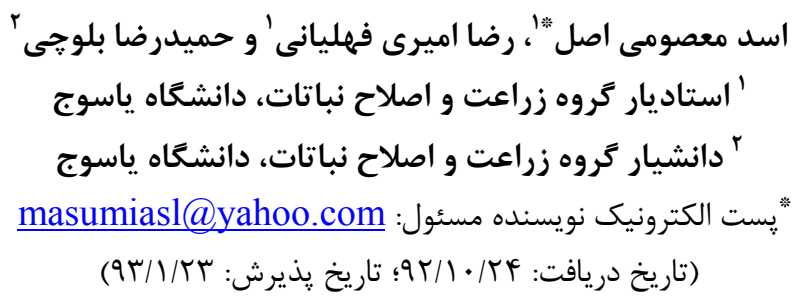

جكيده

تنش شورى يكى از كَتردهترين تنشهاى محيطى بوده و عامل محدود كننده رشد و نمو گياهان زراعى است. يكى از محدوديتهاى اصلى توليد برنج، تنش شورى است. در همين راستا، آزمايشى بهصورت فاكتوريل

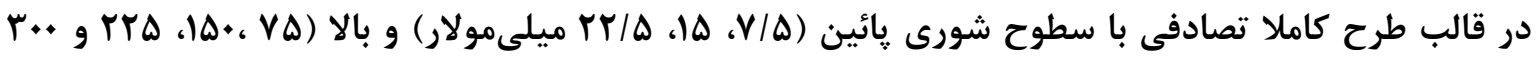
ميلىمولار) بههمراه شاهد به عنوان فاكتور اول و نه رقم برنج (دولار، حسنسرايى، موسىطارم، كامفيروز،

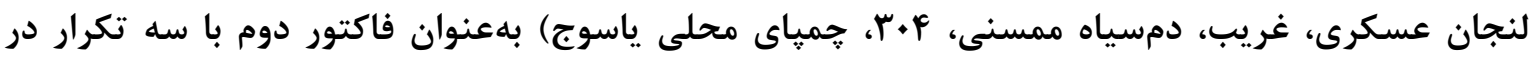
آزمايشگًاه زراعت دانشعاه ياسوج در سال •وسا انجام شد. نتايج نشان دادند كه در سطوح شورى بالا (بيش از له VD ميلىمولار) رقم حسنسرايى با حداكثر درصد جوانهزنى، سرعت جوانهزنى و طول ساقهجه نسبت به شورىهاى اعمالشده متحمل است و رقم دمسياه ممسنى با حداقل صفات مزبور كمترين تحمل را داراست؛ ولى در سطوح شورى يايين (كمتر از ه/ Tr ميلىمولار) با اين كه ارقام حسنسرايى به همراه لنجان و موسىطارم بيشترين درصد جوانهزنى را دارند؛ ولى حداكثر سرعت جوانهزنى به رقم موسىطارم و حداكثر طول ساقه جه به رقم غريب تعلق دارد. بنابراين، از نظر درصد جوانهزنى، رقم حسنسرايى برتر است؛ ولى از نظر حداكثر درصد و سرعت جوانهزنى، رقم موسىطارم برتر بود. يس در تنش شورى بالا نبايد فقط به درصد جوانهزنى متكى بود، بلكه بايد به سرعت جوانهزنى نيز توجه داشت ولى در تنش شورى يايين به علت عدم تمايز ارقام با درصد جوانهزنى بايد صفات سرعت جوانهزنى و وزن خشك ساقهجه بيشتر مورد توجه باشند.

كلمات كليدى: برنج، شورى، درصد جوانهزنى، سرعت جوانهزنى

شورى حساس شده و در مرحله رسيدن دانه به طور

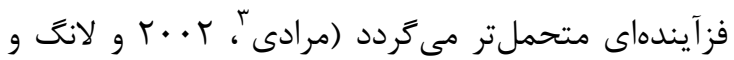

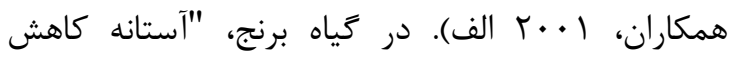
محصول" (حدى كه از آن به بعد كاهش محصول آغاز مى گردد)، سه دسىزيمنس بر متر و گياهى حساس به به به به

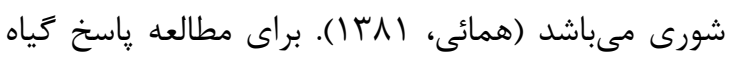
برنج به تنش شورى بهتر است كه اثرات شورى در مراحل

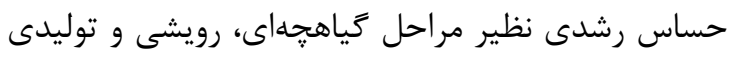

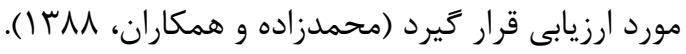

${ }^{3}$ Moradi
مقدمه

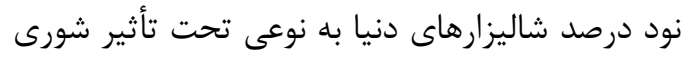

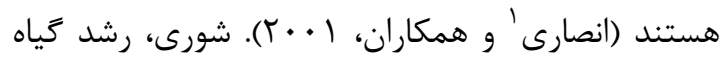
برنج را در مراحل مختلف رشد از جوانهزنى تا رسيدن

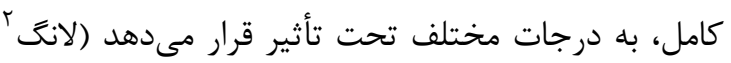

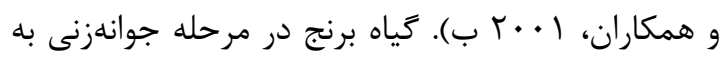
شورى بهطور نسبى متحمل، در اوايل دوره گياهجهاى

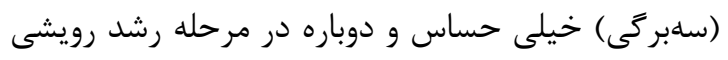
متحمل مى گردد. در مرحله گرده افشانى و لقاح نيز به

\footnotetext{
1 Ansari

${ }^{2}$ Lang
} 
تحقيقات نشان داده كه رقمهاى متحمل داراى سرعت جوانهزنى بيشترى نسبت به رقمهاى حساس مىباشند

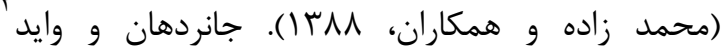
(1911) نيز با مطالعه روى زياه برنج ززارش كردند كه

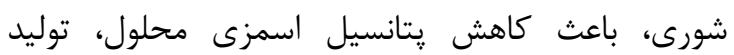
يونهاى سمى و به هم خوردن تعادل عناصر غذايى شده به به به و باعث كاهش درصد جوانهزنى مى شود. شهبازى و كيانى ونى به

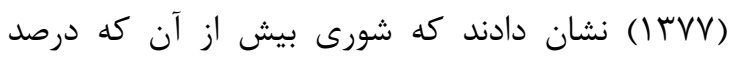
جوانهزنى را كاهش دهد، رشد جوانه، طول و وزن هييوكوتيل و ريشه را تحت تاثير قرار مى دهد.

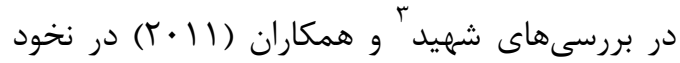

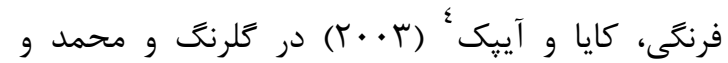

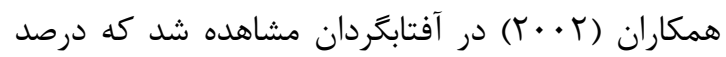
جوانهزنى با افزايش تنش شورى كاهش يافت. بايبوردى و

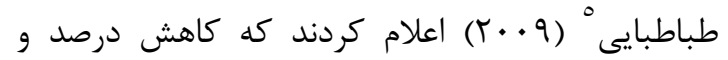
سرعت جوانهزنى با كاهش جذب آب توسط بذر در مرحله آبخيرى و تورزسانس ارتباط دارد. كاهش طول ريشه ساقهجه با افزايش تنش شورى نيز تورسط إس ييلدريم و

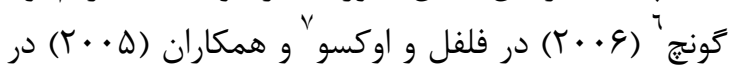

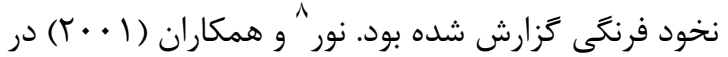
بررسى اثر تنش شورى بر طول ريشهجه 11 رقهم ينبه

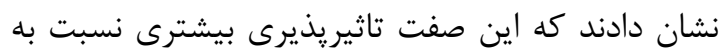
طول ساقهجه داشته و نتيجه گرفتند كه طول ريشه حساسترين قسمت گياه نسبت به اين تنش است.

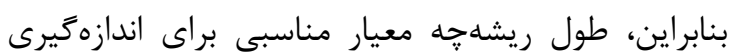
تحمل به تنش شورى در گياهان مختلف است. يافته هاى

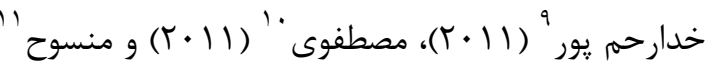

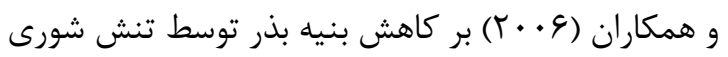
تاكيد داشت.

\footnotetext{
${ }^{2}$ Janrdhan and Vaid Yanaht

${ }^{3}$ Shahid

${ }^{4}$ Kaya and Ipek

${ }^{5}$ Bybordi and Tabatabaei

${ }^{6}$ Yildrim and Goenc

${ }^{7} \mathrm{Oksu}$

${ }^{8}$ Noor

${ }^{9}$ Khodarahmpour

${ }^{10}$ Mostafavi

${ }^{11}$ Mensuh

rI
}

از آنجا كه تحمل به شورى در گياهان، فرآيند ״ييجيدهاى است كه در آن تغييرات مورفولوزيكى، فرآيندهاى فيزيولوزيكى و بيوشيميايى دركير هستند، زنده ماندن و رشد در محيطهاى شور، نتيجه فرآيندهاى

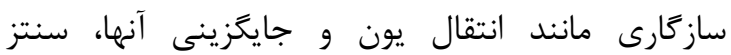
محلولهاى اسمزى و تجمع آنها در جهت تنظيم اسمزى

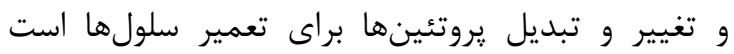

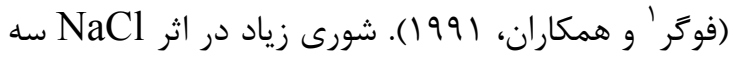

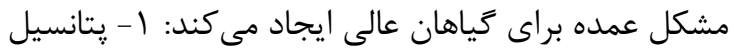

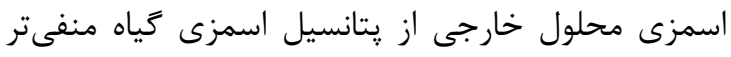

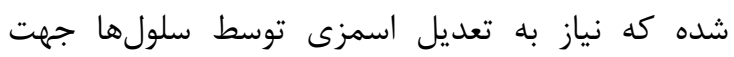

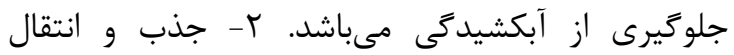
يونهاى غذايى مانند يتاسيم و كلسيم در شرايط سديم زياد مختل مىشود. ب- سديم و كلر در سطوح بالا مىتوانند اثر سميت مستقيم روى غشاها و و سيستمهاى

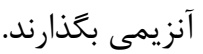
تا كنون برنامههاى بلنزادى به ندرات ندرت موجب افزايش تحمل به شورى شده است، تلاقى ارقام اهلى با خياهان وحشى نيز موجب كاهش يتانسيل عملكرد مىشود. با

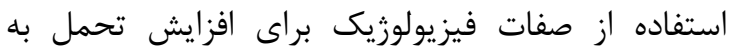
شورى، موفقيتهايى در برنج و گندم حاصل شده است. اخيرا نيز توليد كياهان تراريخته امكانيذير شده، ولى هيج كدام در مزرعه بررسى نشده و استفاده از اين خياهان هنوز راه درازى راد در ييش دارد.

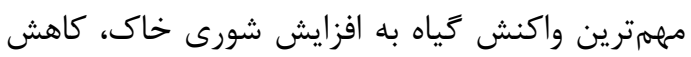
آهنگ رشد است، بلهورى كه منحنى رشد خطى رئ به

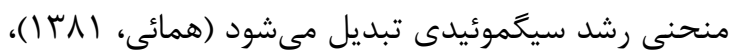

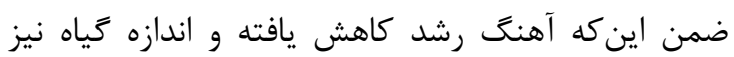
كوجك مىشود. جنانجه گَياه در خاك استقرار يابد، با گذشت زمان و در مراحل بعدى رشد به شورى مقاومتر مىشود. اين مطلب هنوز روشن نيست كه آيا تفاوت گونههاى گياهى از

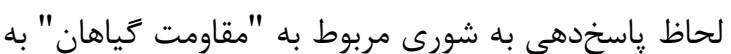

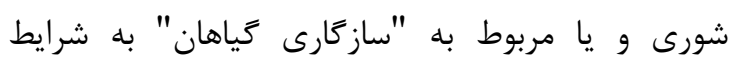
محيطى يا تغذيهاى است كه در آن رشد مى كنند (محمد بأن

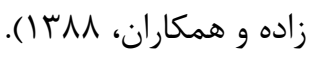

\footnotetext{
${ }^{1}$ Fougere
} 
اندازهگيرى وزن خشك ساقهجه و ريشه جه، نمونهها درون دستخاه آون با دماى VD درجه سانتى

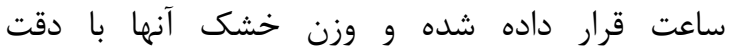

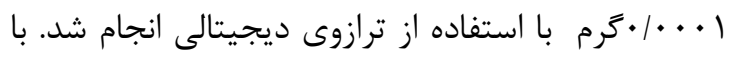

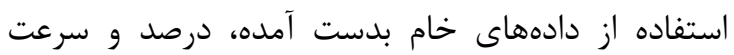
جوانهزنى و نيز بنيه بذر با فرمولهاى زير محاسبه گرديدند:

درصد جوانهزنى= (تعداد كل بذور كشت شده/ تعداد نهايى بذور جوانه زده) ×. سرعت جوانهزنى= (1/ تعداد بذور جوانه زده در روز اول + ז/ تعداد بذور جوانه زده در روز دوم+ ...) بنيه بذر= درصد جوانهزنى × (وزن خشك ريشه جهه +

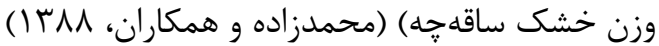
در نهايت، دادهها با استفاده از نرم افـزار آمـارى SAS نسخه و/ تجزيه واريانس و مقايسه ميانخينها با اسـتفاده از آزمون دانكن انجام شد.

\section{نتايج و بحث}

نتايج حاصل از تجزيه واريانس در جدول 1 نشان مىدهد كه سطوح يايين شورى بر درصد جوانهزنى اثر معنى دارى نداشته؛ ولى روى سرعت جوانهزنى در سطح ها هات درصد اثر معنى دار داشته است. اثر متقابل شورى و رقم نيز در مورد صفات سرعت جوانهزنى و طول ريشهجه معنى دار بود. بر اساس جدول rا، بالاترين سرعت جوانهزنى در سطح شورى شاهد متعلق به رقم دولار است ولى در

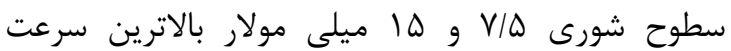
جوانهزنى متعلق به رقم موسىطارم بوده و در سطح

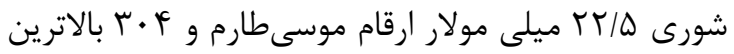
سرعت جوانهزنى را داشتند.
از آنجائى كه واكنش كياه برنج به سطوح شورى

مختلف، متفاوت مىباشد. در تحقيق حاضر قصد داريم با اعمال سطوح مختلف شورى، ياسخ برخى ارقام داخلى و خارجى برنج را از لحاظ شاخصهاى جوانهزنى بررسى نموده و مشخص نمائيم كه كدام يك از شاخصها در سطوح شورى بالا و كدام يك در سطوح شورى يايين بهترين تمايز بين ارقام را بوجود مىآورند.

\section{مواد و روشها}

بdمنظور بررسى اثر تنش شورى روى ارقام متفاوت برنج، آزمايشى به صورت فاكتوريل در قالب طرح كاملاً

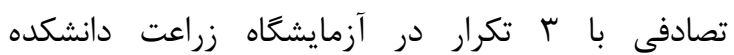
كشاورزى دانشگاه ياسوج انجام گرفت. جهار سطح شورى

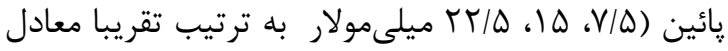
1VD

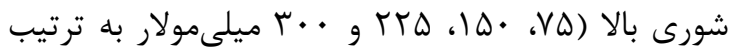
تقريبا معادل بههمراه شاهد به عنوان فاكتور اول و نه رقم برنج (دولار،

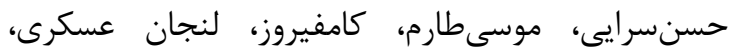

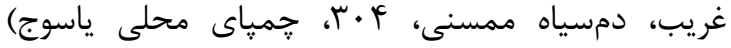
بهعنوان فاكتور دوم مورد استفاده قرار گرفتند. براى انجام

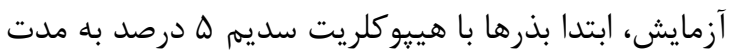

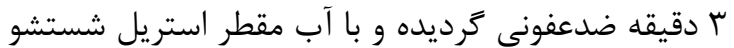
داده شدند. يترى ديشها نيز جهت ضدعفونى، بdمدت

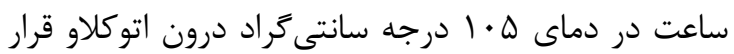
دادهشند. سيس از هر رقم تعداد Dا عدد بذر در هر يترىديش قرار داده شد. يس از ضدعفونى و كاشت بذور، اعمال تنش شورى از روز اول انجام و تعداد بذور جوانهزده

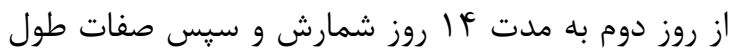
و وزن خشك ساقه جه و ريشهجه اندازهگيرى شدند. براى

جدول 1- تجزيه واريانس ويزگى هاى جوانهزنى بذر برنج در سطوح شورى پايين

\begin{tabular}{|c|c|c|c|c|c|c|c|c|}
\hline بنيه بذر & جوانهزنى درصد & سوانهزنى & ساقه קه & ريشه & وزن خشك & وزن خشك & آزادى & تغنييرات \\
\hline שr & $\cdot / \cdot 1 \mathrm{r}^{\mathrm{ns}}$ & $\cdot / \pi q^{*}$ & $\cdot \mid q \mu \mathrm{V}^{\mathrm{ns}}$ & . /VG ${ }^{\mathrm{ns}}$ & $\cdot / \cdots \cdot \mid r^{\mathrm{ns}}$ & $\cdot|\cdots \cdot \Delta|^{\mathrm{ns}}$ & r & شورى \\
\hline$\cdot / \cdot 1 V \cdot{ }^{* * *}$ & $\cdot 1 \cdot 99^{* * * *}$ & $r / \Lambda \Lambda^{* * *}$ & $r / V V^{* * *}$ & $\Gamma / \mathcal{E V} \varphi^{* * *}$ & $\cdot / \cdots r r^{* * *}$ & $\cdot / \cdots \cdots \wedge \Lambda \cdot^{* * *}$ & $\wedge$ & رقم \\
\hline$\cdot \cdot \Delta r^{\mathrm{ns}}$ & חצr ns & $\cdot / T V \Delta^{* * * *}$ & • & $1 / 1 \Delta V^{*}$ & $\cdot 1 \cdot \cdots r v^{n s}$ & $\cdot / \cdots \cdot \mid v^{n s}$ & Tr & شورى×رقم \\
\hline $.1 . \cdot+\Delta$ & $\cdot / \cdot$ TAF & $\cdot / \cdot r \Lambda$ & - IFFA & . IGTF & $\cdot 1 \cdot \cdots \cdot r r$ & $\cdot 1 \cdot \cdots \cdot \mid 91$ & vr & اشتباه \\
\hline DL & $1 / 99$ & $9 / 7 q$ & rו & $\mid r / \Lambda$ & $\cdot / 1 \wedge \Delta$ &.$/ 1 r q$ & - & $\mathrm{CV}(\%)$ \\
\hline
\end{tabular}


جدول r- مقايسه ميانكَين اثر متقابل شورى و رقم در برخى صفات اندازميرى شده در شورى پاييين

\begin{tabular}{|c|c|c|c|}
\hline طول ريشه جه (ميلى متر) & سرعت جوانهزنى (بذر در روز) & شورى (ميلى مولار) & رقم برنج \\
\hline$r q / 4 \vee b c$ & $11 / 4 \mathrm{~cd}$ & & محلى ياسوج \\
\hline$r q / r \Delta b c$ & $\wedge / \wedge \Delta$ de & & دم سياه \\
\hline سז/س bc & I $/$ $9 \mathrm{~cd}$ & & لنجان \\
\hline$F r / F r b$ & Tr/Fra & & دولار \\
\hline HF/VG bc & $|f / T| \mathrm{bc}$ & • (شاهد) & $r \cdot r$ \\
\hline$r v / q u b$ & $|\Lambda / v| a b$ & & موسى طارم \\
\hline$\checkmark \wedge / Y \backslash a$ & $\mid f / v \& b c$ & & كامفيروز \\
\hline$r r / q 1 \mathrm{c}$ & rr/va e & & حسن سرايى \\
\hline IE/VT C & Ir/Ts c & & 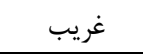 \\
\hline rI/Ar abc & $\mid \Lambda / r \varepsilon a b$ & & محلى ياسوج \\
\hline$r y / / V a b c$ & $1 . / 1 \Delta d$ & & 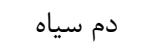 \\
\hline$r F / \Lambda a b c$ & $|r / 9| \mathrm{cd}$ & & لنجان \\
\hline rv/qrab & $|\Delta /| \& b c$ & & دولار \\
\hline$r \Delta / 9 \mathrm{ab}$ & $I T / r \Delta \mathrm{cd}$ & $V / \Delta$ & $r \cdot r$ \\
\hline rN/99 a & Tr/Fta & & موسى طارم \\
\hline$r r / q$ bc & $\mid \Delta /\{\wedge \mathrm{ab}$ & & كامفيروز \\
\hline rI/DSC & $1 . / 48 \mathrm{~d}$ & & حسن سرايى \\
\hline$r V / \Delta / \mathrm{abc}$ & $11 / 9 \mathrm{Vcd}$ & & غريب \\
\hline rq/६q abcd & IV/AT ab & & محلى ياسوج \\
\hline$r \cdot 199 \mathrm{abcd}$ & १/८१ d & & 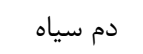 \\
\hline$r F / \wedge \mathrm{cd}$ & I I/Ard & & لنجان \\
\hline$F \Delta / Y F$ a & $19 / \Delta \Delta \mathrm{bc}$ & & دولار \\
\hline$f \cdot / 99 \mathrm{ab}$ & $\mid \mathrm{V} / \cdot 9 \mathrm{bc}$ & 10 & $r \cdot r$ \\
\hline$r \Delta / ৭ \& \mathrm{abc}$ & $r Y / A \mid$ a & & موسى طارم \\
\hline$r F / F \mathrm{~cd}$ & $19 / T r \mathrm{bc}$ & & كامفيروز \\
\hline TI/DS d & $1 \% / 99 \mathrm{c}$ & & حسن سرايى \\
\hline$r \wedge / F \wedge$ bcd & $\mid r / F V$ cd & & غريب \\
\hline$r V / \& \wedge a b$ & $1 / / r \& b$ & & محلى ياسوج \\
\hline Ir/VFd & $\Lambda / r \mathrm{e}$ & & دم سياه \\
\hline$r F / / b c$ & $11 / 99 \mathrm{~cd}$ & & 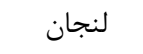 \\
\hline ऍN/૬9 a & Ir/VF cd & & دولار \\
\hline זN/rı a & $|N / V| a$ & $r$ r/D & $r \cdot r$ \\
\hline ry/ve ab & $19 / r \Delta \mathrm{a}$ & & موسى طارم \\
\hline$r \cdot / v r$ a & $10 / 19 \mathrm{c}$ & & كامفيروز \\
\hline$r q / \cdot r a b c$ & $9 / 11 \mathrm{e}$ & & حسن سرايى \\
\hline $\mathrm{rV} / .9 \mathrm{abc}$ & $1 \cdot 1 \cdot r \mathrm{de}$ & & 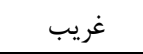 \\
\hline
\end{tabular}

شاهد متعلق به رقم كامفيروز است ولى اين برترى در

سطوح شورى بعدى بهترتيب به ارقام موسى طارم و دولار

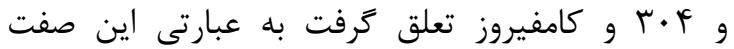

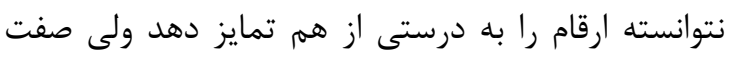

r
رقم موسىطارم از نظر سرعت جوانهزنى بر ساير ارقام

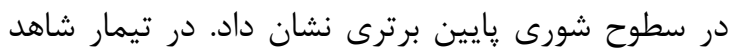
نيز اختلاف رقم موسى طارم از رقم دولار از نظر اين صفت

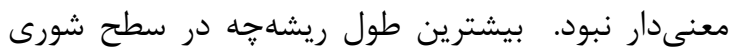


نتوانسته درصد جوانهزنى و بنيه بذر را بصورت معنىدار تغيير دهد؛ ولى سرعت جوانهزنى حتى در سطوح شورى هايين متاثر كرديده است.
سرعت جوانهزنى عليرغم داشتن اثرات متقابل، در تمايز ارقام خوب عمل مى كند. بنيه بذر نيز در اثر سطوح شورى اندي

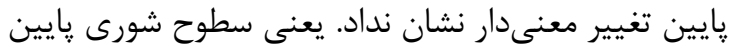

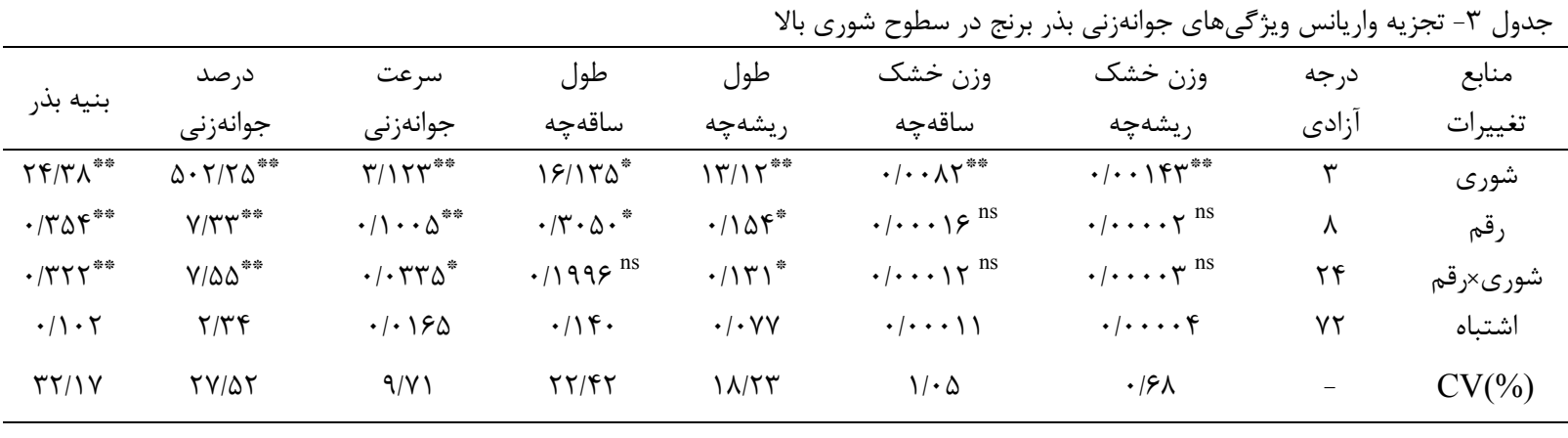

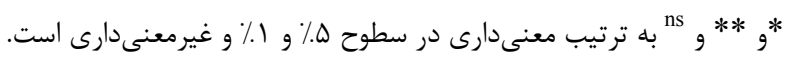

تمايزى بين ارقام نشان دهد و در شورىهاى بالاتر جون

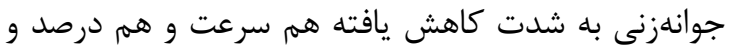
هم طول ريشهجه و بنيه بذر نتوانستهاند در تمايز دادن ارقام كمكى بكنند. بنابراين بنظر مىرسد شورىهاى نتئ خيلى بالا هيج كمكى در تمايز ارقام به محقق نخواهند كرد ولى شورىهاى يايين و متوسط در اين مورد موفقتر

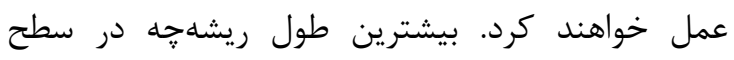
شورى VD و •D ميلىمولار بهترتيب متعلق به ارقام دولار

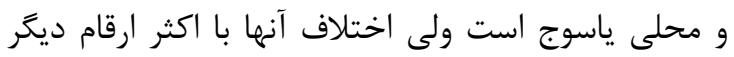

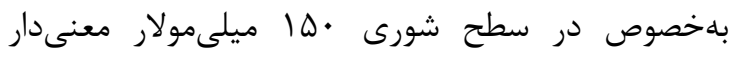
نيست. به عبارتى اين صفت نتوانسته ارقام را به درستى از داز هم تمايز دهد در مورد صفات بنيه بذر نيز وضعيتى مشابه

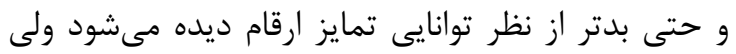
صفت سرعت جوانهزنى در سطوح شورى بالا نيز عليرغم داشتن اثرات متقابل، در تمايز ارقام خوب عمل كردات درده

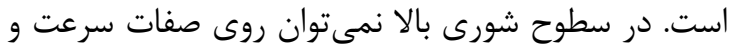
درصد جوانهزنى و بنيه بذر بصورت مستقل بحث كرد بالني

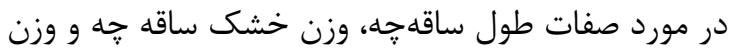
خشك ريشهجه جون اثر متقابل معنى دار نيست مىتوان روى اين صفات بطور مستقل بحث كرد.
نتايج تجزيه واريانس حاصل از دادههاى مربوط به بررسى اثر سطوح شورى بالا (•ا برابر سطوح شورى

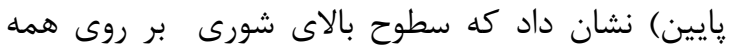
صفات اثر معنىدارى داشتهاست (جدول بان). اثر متقابل

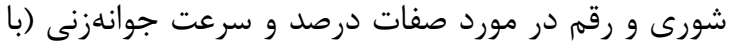

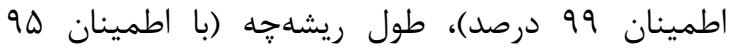
درصد) و بنيه بذر (با اطمينان 99 درصد) معنىدار بود. بر الطران اساس جدول ثا، بالاترين سرعت جوانهزنى در سطح

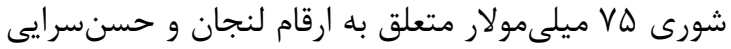
مىباشد ولى با ارقام محلى ياسوج، دم سياه و و كامفيروز

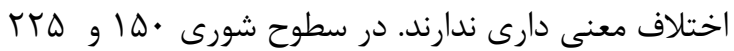
ميلىمولار بالاترين سرعت جوانهزنى متعلق يه رقم حسن احن سرايى مىباشد، هرجند در سطح شورى • ال ميلى مولار اختلاف بين ارقام حسنسرايى و غريب از نظر اين صفت هن معنى دار نبود. رقم حسنسرايى از نظر سرعت جوانهزنى بر ساير ارقام در سطوح شورى بالا برترى نشان مى دهدي.

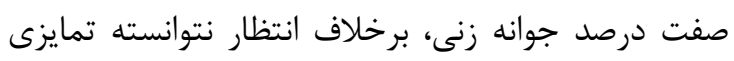
بين ارقام ايجاد نمايد و تقريبا همه ارقام در يك گرقروه قرار

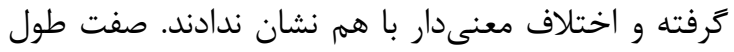

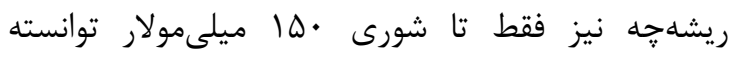




\begin{tabular}{|c|c|c|c|c|c|}
\hline بنيه بذر & 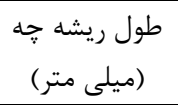 & درصد جوانه زنى & سرعت جوانهزنى & 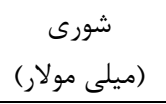 & رقم \\
\hline r/9 T a & $\Gamma / \wedge b c$ & $q \xi / 4 r$ a & $1 / 99 \mathrm{ab}$ & & محلى ياسوج \\
\hline ra & $r / r c$ & $9 \& / 4 Y$ a & $\mathrm{r} / .4 \mathrm{ab}$ & & دم سياه \\
\hline$r / l V a$ & G/NF ab & $91 / r \mathrm{a}$ & $r / 4 \varphi \mathrm{a}$ & & لنجان \\
\hline$r / r$ a & $1 / 91 \mathrm{a}$ & $9 \Lambda / r a$ & $1 / 4 r b$ & & دولار \\
\hline ra & f/ç bc & $94|9| \mathrm{a}$ & $1 / 4 \& b$ & $v \Delta$ & $r \cdot r$ \\
\hline$r / r \wedge a$ & $\mathrm{r} / \Delta \wedge \mathrm{c}$ & $\Lambda N / 1 \backslash a$ & $1 / 09 \mathrm{~b}$ & & موسى طارم \\
\hline T/YF ab & $4 / \% q \mathrm{c}$ & NG/Tra & $r / \cdot 9 \mathrm{ab}$ & & كامفيروز \\
\hline $\mathrm{r} / 19 \mathrm{a}$ & $\varepsilon / \Delta s \mathrm{ab}$ & $9 \Lambda / r \mathrm{a}$ & $r / \Delta V a$ & & حسن سرايى \\
\hline$\cdot / V F b$ & $r / \cdot r c$ & b שسאץ b & $1 / \Delta \varphi b$ & & غريب \\
\hline$T / 9 \Delta \mathrm{ab}$ & $r / \Lambda \Lambda a$ & $94 / .9 \mathrm{a}$ & $1 / 4 \&$ bcd & & محلى ياسوج \\
\hline $.1 .9 \mathrm{c}$ & $\cdot / \Delta \wedge \mathrm{c}$ & $r \varepsilon / \Delta \wedge a$ & $\cdot 1 \Delta \& \mathrm{f}$ & & دم سياه \\
\hline r/৭९ a & $r / \Delta r a b$ & $94|9| \mathrm{a}$ & I/VT abc & & لنجان \\
\hline$r / 4 \& a b$ &.$/ 99 \mathrm{c}$ & ^9/^r a & $.19 \mathrm{def}$ & & دولار \\
\hline$r / \& q a b$ & $1 / T y a b c$ & $91 / \Delta F a$ &.$/ 91$ def & 10 & $r \cdot r$ \\
\hline $1 / \cdot F b c$ & $1 / T r \mathrm{bc}$ & 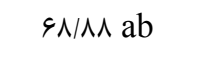 & - Mr ef & & موسى طارم \\
\hline 1/ब9 ab & I/G $\mathrm{abc}$ & $V \wedge / T \backslash$ a & $1 / T \Delta$ cde & & كامفيروز \\
\hline$r / 9 \Delta \mathrm{ab}$ & 1/4 $\mathrm{abc}$ & $94 / .9 \mathrm{a}$ & $r / r \wedge a$ & & حسن سرايى \\
\hline$r / \cdot \varphi \mathrm{ab}$ & $r / \wedge a$ & $\Lambda F / \Delta \&$ a & $1 / 99 \mathrm{ab}$ & & غريب \\
\hline$\cdot \mathrm{c}$ & $\cdot \mathrm{a}$ & $\cdot \mathrm{c}$ & $\cdot b$ & & محلى ياسوج \\
\hline$\cdot \mathrm{c}$ & $\cdot \mathrm{a}$ & $\cdot \mathrm{c}$ & $\cdot b$ & & دم سياه \\
\hline$\cdot c$ & $\cdot \mathrm{a}$ & $\cdot c$ & $\cdot b$ & & لنجان \\
\hline$\cdot \mathrm{c}$ & $\cdot \mathrm{a}$ & $\cdot \mathrm{c}$ & $\cdot b$ & & دولار \\
\hline$\cdot \mathrm{c}$ &.$/ \cdot 1 \mathrm{fa}$ & $\Delta / r \Delta c$ & $\cdot b$ & TTS & $r \cdot r$ \\
\hline$\cdot c$ & $\cdot \mathrm{a}$ & $\cdot c$ & $\cdot / \cdot 1 / \mathrm{b}$ & & موسى طارم \\
\hline$\cdot \mathrm{c}$ & $\cdot 1 \cdot r \mathrm{a}$ & GIAF C & $\cdot b$ & & كامفيروز \\
\hline $1 / 4 r a$ & $.1 .9 \mathrm{a}$ & V\&/T\& a & $\cdot / l \cdot r a$ & & حسن سرايى \\
\hline$\cdot b$ & $\cdot / \cdot \wedge r \mathrm{a}$ & $\mathrm{r} / / \mathrm{s} \mathrm{b}$ & $\cdot / v \mid b$ & & غريب \\
\hline$\cdot \mathrm{a}$ & $\cdot \mathrm{a}$ & $\cdot \mathrm{a}$ & $\cdot \mathrm{a}$ & & محلى ياسوج \\
\hline$\cdot \mathrm{a}$ & $\cdot \mathrm{a}$ & $\cdot \mathrm{a}$ & $\cdot \mathrm{a}$ & & دم سياه \\
\hline$\cdot \mathrm{a}$ & $\cdot \mathrm{a}$ & $\cdot \mathrm{a}$ & $\cdot \mathrm{a}$ & & لنجان \\
\hline$\cdot \mathrm{a}$ & $\cdot \mathrm{a}$ & $\cdot \mathrm{a}$ & $\cdot \mathrm{a}$ & & دولار \\
\hline$\cdot a$ & $\cdot \mathrm{a}$ & $\cdot \mathrm{a}$ & $\cdot a$ & $r \cdot$. & $r \cdot r$ \\
\hline$\cdot \mathrm{a}$ & $\cdot \mathrm{a}$ & $\cdot \mathrm{a}$ & $\cdot \mathrm{a}$ & & موسى طارم \\
\hline$\cdot \mathrm{a}$ & $\cdot a$ & $\cdot \mathrm{a}$ & $\cdot \mathrm{a}$ & & كامفيروز \\
\hline$\cdot \mathrm{a}$ & $\cdot \mathrm{a}$ & $\cdot \mathrm{a}$ & $\cdot \mathrm{a}$ & & حسن سرايى \\
\hline$\cdot \mathrm{a}$ & $\cdot \mathrm{a}$ & $\cdot \mathrm{a}$ & $\cdot \mathrm{a}$ & & غريب \\
\hline
\end{tabular}

$$
\text { ارنابراين، مىتوان نتيجهَيرى كرد كه اكر هدف تمايز }
$$




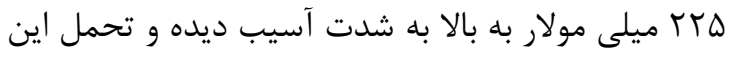

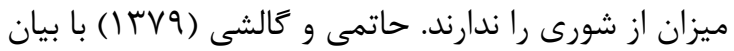
اين كه افزايش سطح شورى باعث كاهش سرعت

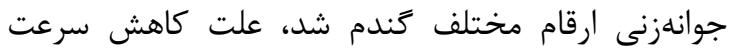
جوانهزنى را افت يتانسيل آب و كاهش امكان جذب آب آب توسط بذر ارزيابى كردند. در تحقيق حاضر نيز شايد بتوان

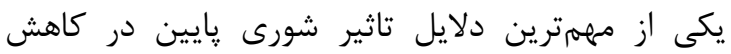
سرعت جوانهزنى همين عامل باشد.
نتايج مقايسه ميانكَين صفات مختلف در سطوح شورى با مقادير زياد شورى (جدول ه) نشان داد كه در سطوح

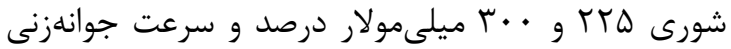

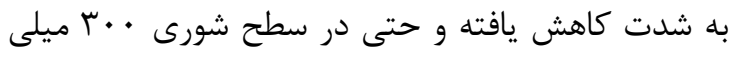

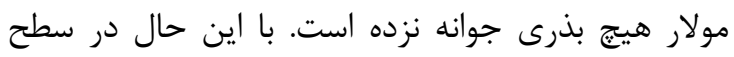
شورى •لا ميلىمولار حدود •1 درصد جوانهزنى ديده

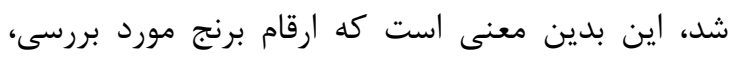

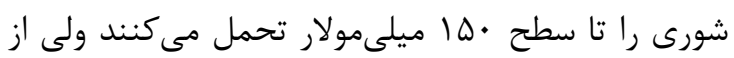

جدول ه- مقايسه ميانگين ويزَىىهاى جوانهزنى بذر برنج در سطوح شورى بالا

\begin{tabular}{|c|c|c|c|c|c|c|c|}
\hline بنيه بذر & درصد جوانهزنى & سرعت جوانهزنى (بذر در روز) & طول ساقه ֶ) & طول ريشهُ ֶه & وزن خشك ساقه گه & وزن خشك ريشه & 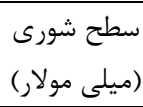 \\
\hline $1 / 9 \cdot a$ & $\Lambda \Lambda / \Delta a$ & $1 / \mathrm{Va}$ & r/gr a & $r / F V a$ & $1 / . r 4 a$ & $1 / \cdot 10 \mathrm{a}$ & $V \Delta$ \\
\hline $1 / v \cdot b$ & $\Lambda \cdot / r a$ & $1 / \Delta T \mathrm{~b}$ & $1 / 9 \vee b$ & l/gk b & $1 / \cdot r r b$ & $1 / . .9 \mathrm{~b}$ & 10. \\
\hline . / MF c & \&/GT b & $1 / \cdot \wedge \mathrm{c}$ & $1 / \cdot \wedge \mathrm{c}$ & $1 . .911 \mathrm{c}$ & $1 / \cdots \mid \vee c$ & $1 / \cdots 1 \mathrm{c}$ & TTD \\
\hline$\cdot / \cdot r \mathrm{c}$ & - c & $\cdot d$ & $1 / . . r c$ & $1 \mathrm{c}$ & $1 \mathrm{c}$ & $1 \mathrm{c}$ & r.. \\
\hline
\end{tabular}

در هر ستون ميانخينهايى كه داراى حروف مشابه هستند، در سطح احتمال ه درصد اختلاف معنىدار ندارند.

جدول 9- مقايسه ميانكَين ويزگى هاى جوانهنى بذر برنج در سطوح شورى پايين

\begin{tabular}{|c|c|c|c|c|c|c|c|}
\hline بنيه بذر & جوانهزنى & سرعت جوانهزنى & طول ساقه & 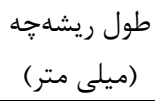 & وزن خشك ساقه & وزن خشك ريشه & 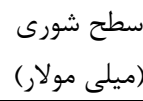 \\
\hline$r / \cdots V a$ & $91 / r a$ & r/VG b & $\Delta / r a$ & $\Delta / 9 \vee a$ & $1 / .94 a$ & $1 / \cdots+\varepsilon a$ & . \\
\hline $1 / 91 \wedge \mathrm{a}$ & $q V / r a$ & $\Gamma / \wedge \wedge a b$ & $r / 91 \mathrm{a}$ & $\Delta / \& \mathrm{a}$ & $1 / . .9 \vee \mathrm{a}$ & $1 / \cdots r r A b$ & $V / Q$ \\
\hline $1 / 99 \wedge \mathrm{a}$ & $9 \vee / \wedge a$ & $f / \cdot 1 \mathrm{a}$ & $\Delta / \cdot r a$ & $\Delta / 9 \mathrm{a}$ & $1 / .94 \mathrm{a} a$ & $1 / \cdots r q b$ & 10 \\
\hline$r / \cdots \wedge \mathrm{a}$ & $q \Lambda / r$ a & r/ץ b & $\Delta / r a$ & $\Delta / \& \mathrm{a}$ & $1 / \cdots v \cdot a$ & $1 / . \cdots r b$ & $T r / D$ \\
\hline
\end{tabular}

در هر ستون ميانگين هايى كه داراى حروف مشابه هستند، در سطح احتمال ه درصد اختلاف معنى دار ندارند.

شورى را دارند. شجيع و همكاران (INAF)

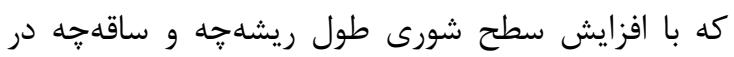
لوبياى جيرفتى كاهش يافت. طبق زَارشات گواهى و

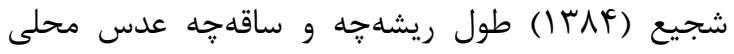

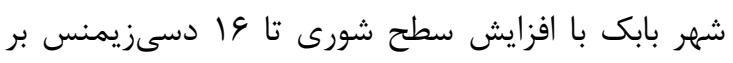
متر كاهش يافته و طول ساقهجه بيشتر از ريشهجه تح تحت

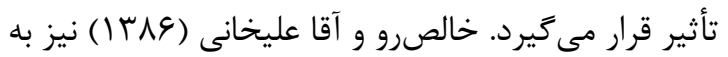

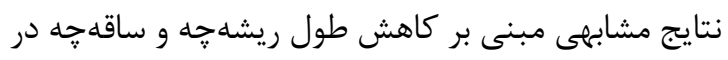

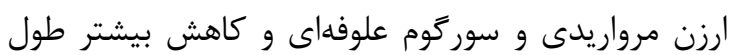
ساقهجه نسبت به طول ريشهجه اشاره كردند. در زياهان سياهدانه، اسفرزه و خلر نيز با افزايش سطوح شورى طول ريشه جه و ساقه ֶه كاهش يافت (صفرنزاد و همكاران،

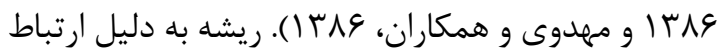
مستقيم با شورى بيشتر از ساير اندامها در معرض تنش
بنابراين، در ارقام مورد بررسى حداكثر سطح شورى

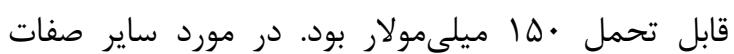
مورد بررسى نيز با افزايش سطح شورى روند كاهشى ديده مىشود ولى اين كاهش در مورد صفات طول ساقهجه و طول ريشهجه و بنيه بذر شديدتر از بقيه صفات بود. در مر مورد همه صفات اختلاف سطح اول و دوم شورى معنى دار بوده ولى اختلاف بين سطوح سوم و جهارم شورى به جز در مورد درصد و سرعت جوانهزنى در مورد بقيه صفات

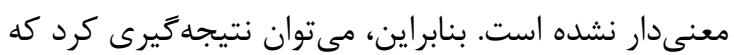
اتر بخواهيم با حضور شورى بالا ارقام را از هم متمايز

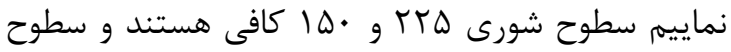
شورى بالاتر توصيه نمىشود. از طرف ديگر، بهغير از صفت درصد جوانهنى ساير صفات از جمله سرعت جوانهزنى نيز توان ايجاد اختلاف معنى دار بين سطح 
جوانهزنى ندارند ولى سرعت جوانهزنى توانست ارقام را با

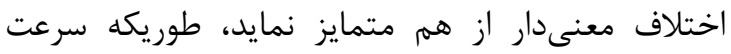

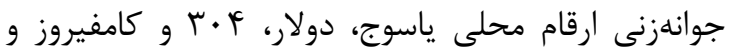
همينطور دمسياه و حسنسرائى و نيز غريب و لنجان

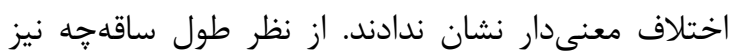

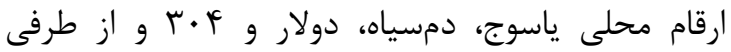

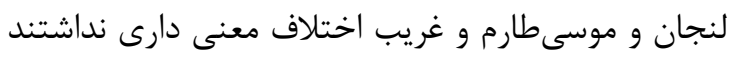

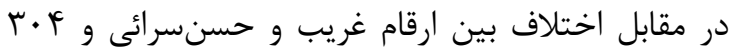
معنى دار بود. در مورد ساير صفات نيز وضعيت تمايز ارقام بهتر از درصد جوانهزنى است (وضعيت بقيه صفات در

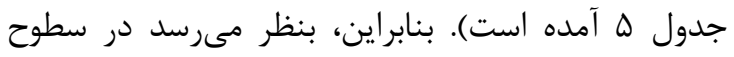
شورى بايين، اكثر صفات مورد بررسى در تمايز دادن ارقام

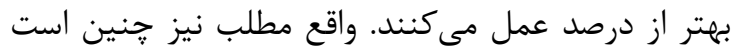

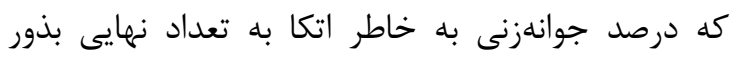

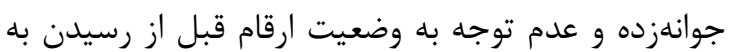
تعداد نهايى بذور جوانهزده، در تمايز ارقام موفق نيست و بهتر است علاوه بر درصد، به ساير صفات نيز بخصوص در سطوح پإيين شورى توجه شود. مقايسه ميانگين ارقام در سطوح شورى بالا در جدول ᄉ نشان داد كه به غير از حسنسرائى، همه ارقام در يك إنى

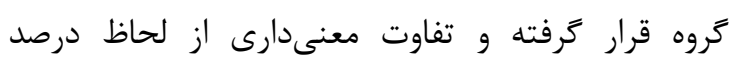
جوانهزنى ندارند ولى سرعت جوانهزنى توانست ارقام را با فار اختلاف معنىدار از هم متمايز نمايد، طوريكه سرعت

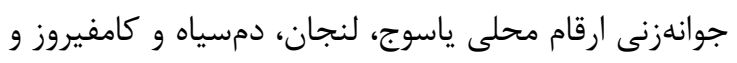

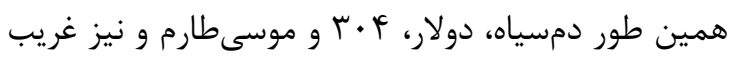

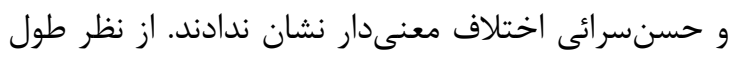

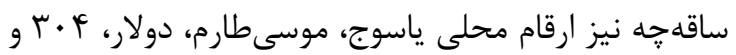
غريب اختلاف معنى دارى نداشتند. در مقابل، اختلاف بين ارقام دمسياه و لنجان و حسنسرائى معنىدار بود. در مورد ساير صفات نيز وضعيت تمايز ارقام بهتر از درصد جوانهزنى است. بنابراين، بنظر مىرسد در سطوح شورى بالا نيز هماند سطوح شورى پايين، اكثر صفات مورد

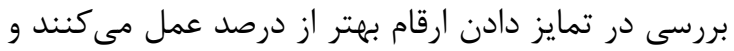
بهتر است علاوه بر درصد، به ساير صفات نيز توجه شود، إندان هرجند بنظر مىرسد ساير صفات در سطوح شورى بإيين حتى بهتر از سطوح شورى بالا عمل مى كنند و اختلافات را بهتر نشان مىدهند. بر اساس نتايج محمدزاده و tr
شورى مىباشد و بهعنوان يك فيلتر، عبور يونها را كنترل مى كند و نسبت مطلوب يونهاى سديم و يتاسيم را براى فعاليتهاى سلول فراهم مىسازد، به نظر مىرسد بـ به اين

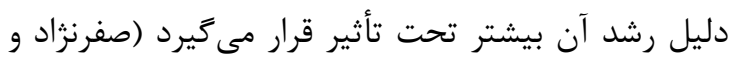

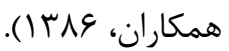
يارنيا و همكاران (•^r||) نشان دادند كه شورى موجب افزايش نسبت ريشه به ساقه مى كردد. دليل اين اين إندان يديده اين مىباشد كه در محيط تنش كياه انرزى بيشترى براى استقرار و رشد ريشه مصرف مى كند و به همين دليل

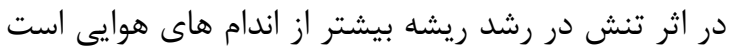

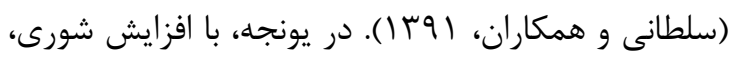

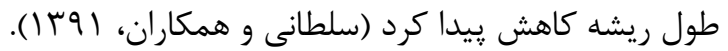
نتايج مقايسه ميانخين صفات مختلف در سطوح شورى קإيين در جدول 9 نشان داد كه سطوح شورى يايين در

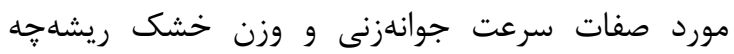
تفاوتهاى معنى دار ايجاد كردند ولى درمورد ساير صفات و حتى بنيه بذر تفاوت معنىدار ايجاد نكرده است.

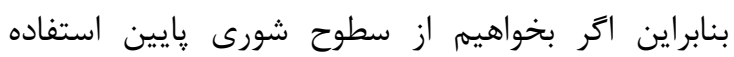
نماييم، درصد جوانهزنى بين سطوح مختلف شورى آنسين تمايزى ايجاد نمى كند ولى صفات سرعت جوانهزنى وزن دان إنى

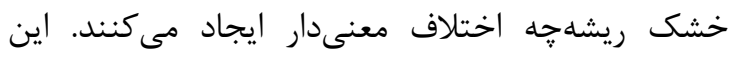
وضعيت در مورد ارقامى كه بذر بسيار كمى از آنها داشته

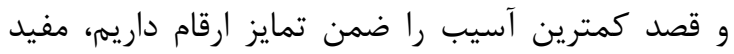

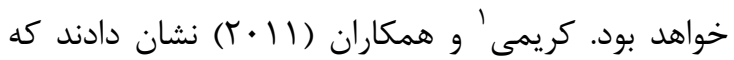

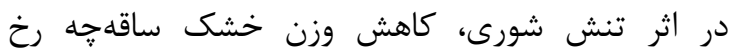

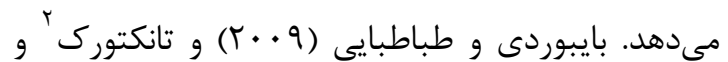

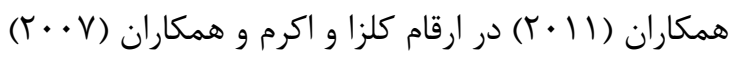
در آفتابكردان نشان دادند كه تنش شورى باعث كاهش

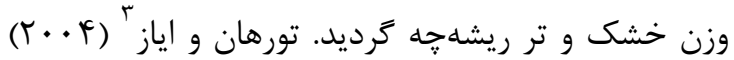
دريافتند كه افزايش سطوح شورى با اثر بر روى تقسيم

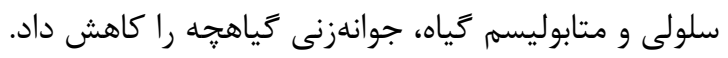
مقايسه ميانكَين ارقام در سطوح شورى يايين در

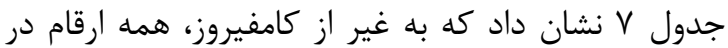

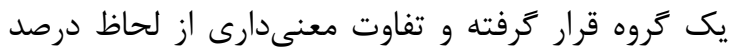

\footnotetext{
${ }^{1}$ Karimi

2 Tunçtürk

${ }^{3}$ Turhan and Ayaz
} 
جوانهزنى همبستگى معنى دار نشان داد. طول ريشه جه نيز با طول ساقه جه، وزن خشك ريشه

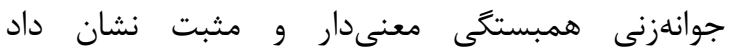

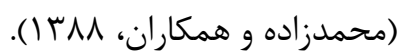

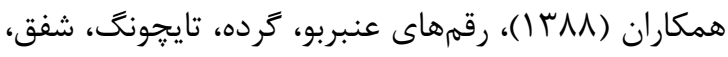
حسنسرايى و غريب تحمل خوبى نسبت به تنش سورى داشتند (محمدزاده و همكارن،

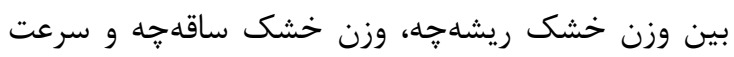

جدول V- مقايسه ميانگَين ارقام برنج براى شاخصهاى جوانهزنى در سطوح شورى بايين

\begin{tabular}{|c|c|c|c|c|c|c|c|}
\hline درصد جوانه زنى & بنيه بذر & 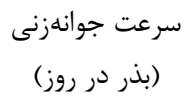 & طول ساقه جهـ & 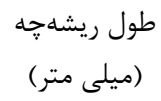 & 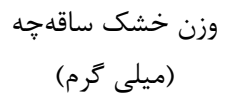 & 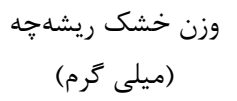 & رقم برنج \\
\hline$q \vee / \Delta a$ & $r / \cdots \wedge \mathrm{a}$ & $19 / \pi \wedge \mathrm{b}$ & $r \Delta / \& \mathrm{bcd}$ & $r T / / \mathrm{bc}$ & $.1 \cdot 1 \mathrm{krb}$ & $.1 .99 \mathrm{ab}$ & محلى ياسوج \\
\hline$৭ ९ / \wedge \mathrm{a}$ & $1 / 9 V^{c} \mathrm{a}$ & $9 / \Gamma \mathrm{d}$ & $r \cdot / / \mathrm{de}$ & $r \varepsilon / \Gamma \mathrm{cd}$ & $\cdot / \wedge \mathrm{e}$ & $.1 . .4 \mathrm{c}$ & دم سياه \\
\hline $1 \cdots a$ & $r / \cdot r \cdot a$ & $I T / T \mathrm{c}$ & rA/ $\mathrm{abc}$ & T\&/\& cd & $\cdot|\cdot| f \mid \mathrm{bcd}$ & $\cdot / \cdot \wedge \mathrm{ab}$ & ل لنجان \\
\hline $9 \wedge / 1 \mathrm{a}$ & $r / \cdot r \Delta a$ & $19 / \wedge \mathrm{b}$ & r r/f cde & $f \cdot / 1 a$ &.$/ .1 \mathrm{fabcd}$ & $\cdot / \cdot 1 \cdot \mathrm{a}$ & دولار \\
\hline qV/A a & $\tau / \cdot \Delta \mathrm{a}$ & $1 \Delta / \Delta b$ & $r \Delta / V$ bcd & $r v / r a b$ & $.1 \cdot 1 \mathrm{kfbc}$ & $\cdot 1 \cdot 1 \cdot \mathrm{a}$ & $r \cdot r$ \\
\hline $1 \cdots a$ & $r / \cdot r F a$ & $r \cdot / \Lambda a$ & $r / / \mathrm{ab}$ & r $4 / \wedge \mathrm{ab}$ & $\cdot 1 \cdot 11 \cdot \mathrm{a}$ & $.1 .99 \mathrm{a}$ & موسى طارم \\
\hline$q \mu / 9 \mathrm{~b}$ & $1 / 919 \mathrm{~b}$ & $1 \Delta / \Delta b$ & $19 / 4 \mathrm{e}$ & rq/ & $\cdot / \cdot 1 \cdot$ cde & $\cdot / \cdot \wedge \wedge \mathrm{ab}$ & كامفيروز \\
\hline $1 \cdots a$ & $r / r \cdot r \cdot a$ & $9 / 4 \& \mathrm{~d}$ & $r / / r \mathrm{de}$ & $r r / V d$ & $.1 .11 \mathrm{de}$ & $.1 . \cdot 9 \mathrm{c}$ & حسن سرايى \\
\hline$q \vee / r a$ & $1 / 99 \cdot a$ & $11 / 1 \mathrm{c}$ & rr/f a & $r V / r \mathrm{~cd}$ & $.1 \cdot 1 \& \mathrm{bcd}$ & $\cdot 1 \cdot \vee \vee b c$ & غريب \\
\hline
\end{tabular}

جدول ^- مقايسه ميانگين ارقام برنج براى شاخصهاى جوانهزنى در سطوح شورى بالا

\begin{tabular}{|c|c|c|c|c|c|c|c|}
\hline جوانهزنى & بنيه بذر & سرعت جوانهزنى & طول ساقه & طول ريشه & وزن خشك ساقه جهـ & وزن خشك ريشه جه & رقم برنج \\
\hline$r \wedge b$ &.$/ 9 \wedge \Delta \mathrm{b}$ & $\cdot / V \& b c$ & $1 / 1 \pi \mathrm{bc}$ & l/gr a & $\cdot|\cdot r r| \mathrm{ab}$ & $\cdot / \cdot \wedge \wedge \mathrm{a}$ & محلى ياسوج \\
\hline $19 / r \Delta b$ & $\cdot / V \& \vee b$ & $\cdot \mid \Delta \Phi \mathrm{C}$ & $.19 \mathrm{c}$ & $\cdot / V V b$ & $\cdot / \cdot \mid \Delta \& b$ &.$/ \cdot 14 \varepsilon a$ & دم سياه \\
\hline TN/A b & $1 / \cdot 19 b$ & $\cdot / \wedge \vee b$ & $r / M F a$ & $1 / \mathrm{V} \wedge \mathrm{a}$ & •।. rvq a & $\cdot / \cdot 1 \cdot \wedge \mathrm{a}$ & لنجان \\
\hline$r V / A b$ &.$/ 9 \wedge \vee b$ & . $/ \Delta \mathrm{HC}$ & $r / r V$ abc & $1 / 8 \mathrm{ra}$ & .. rvq a & $\cdot 1 \cdot 10 \cdot a$ & دولار \\
\hline r $b$ & $1 / \cdot r q b$ & $\cdot 1 \Delta 9 \mathrm{c}$ & I/Ar abc & $1 / 19 a b$ & $\cdot / \cdot r \wedge \& \mathrm{ab}$ & $\cdot / \cdot \wedge \& \mathrm{a}$ & $r \cdot r$ \\
\hline$r+\Delta \mathrm{b}$ & $\cdot / A r q b$ & . $/ \Delta \mathrm{HC}$ & I/GY abc & . $199 \mathrm{ab}$ & $\cdot / \cdot r \backslash \wedge \mathrm{ab}$ & $\cdot 1 \cdot \cdot \wedge \cdot a$ & موسى طارم \\
\hline$r q / \mu \mathrm{b}$ & $\cdot / 9 r \cdot b$ & $\cdot / V \vee b c$ & $r / \mu$ ac & $1 / 19 a b$ & $\cdot / \cdot r \Delta I \mathrm{ab}$ & $\cdot 1 \cdot \cdot \wedge f$ a & كامفيروز \\
\hline$\Delta r / l a$ & I/r人fa & $1 / r \Delta \mathrm{a}$ & $r / r \wedge a$ & $1 / \Delta \& \mathrm{a}$ & $\cdot 1 \cdot \Delta \cdot 9 \mathrm{ab}$ & $\cdot / \cdot 1 r \cdot a$ & حسن سرايى \\
\hline $\mathrm{r} / \mathrm{\Delta} \mathrm{b}$ &.$/ 99 \wedge \mathrm{b}$ & $.199 \mathrm{ab}$ & $r / l r a b$ & $1 / 4 r a b$ & . - rrr ab & $\cdot / \cdot 1 \cdot \cdots a$ & غريب \\
\hline
\end{tabular}

در هر ستون ميانگينهايى كه داراى حروف مشابه هستند، در سطح احتمال ه درصد اختلاف معنى دار ندارند.

\section{نتيجه گيرى \\ آكيتا و كابوسلاى' (·99 (19) نيز نتايج مشابهى را روى}

ياسخ ارقام مختلف برنج به سطوح شورى مختلف

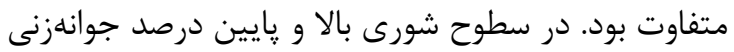
نتوانسته در تمايز ارقام موفق باشد ولى سرعت جوانهزنى از اين جهت قوىتر عمل كردهاست. صفات درصد و سرعت جوانهزنى، وزن تر و خشك ساقهجه و ريشه همجنين طول ساقه ֶه و ريشه جه با افزايش سطوح

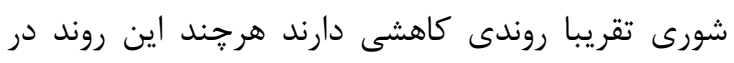
سطوح شورى بالا منظهمتر ولى در سطوح شورى يايين روند منظمى نداشته و كاهى شورى ملايم باعث بهبود ارقام برنج گزارش كردند. آنها با مقايسه سه سطح شورى

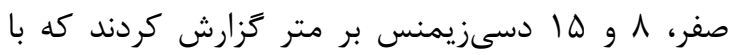
زياد شدن شدت تنش شورى، وزن خشك ريشه ساقهجه كاهش مىيابد. در تحقيق حاضر، طول ريشهُ ساقه جه با افزايش شورى در تمامى رقمها كاهش يافت.

\footnotetext{
${ }^{1}$ Akita and Cabuslay
} 
شورى يايين در جهت تمايز ارقام تكرار نشده و اتر فقط

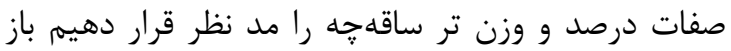
هم رقم حسنسرائى تمايز نشان مى دهد.

تقدير و تشكر

از دانشجويان عزيز خانمها شهناز طاهرى بويراحمدى،

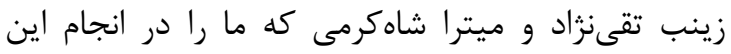
يروزه يارى دادهاند كمال تشكر را داريم.
برخى صفات شده است. در سطوح شورى بالا، رقم حسنسر ايى با حداكثر درصد جوانهزنى، سرعت جوانهزنى،

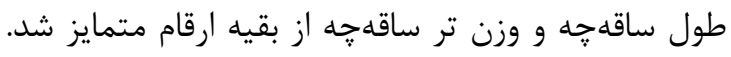
در سطوح شورى بايين با اينكه رقم حسنسرائى به همراه

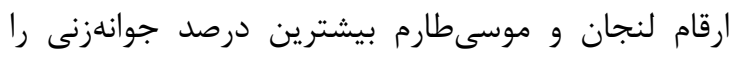

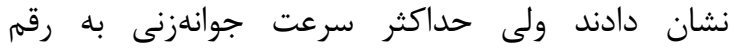
موسى طارم، حداكثر طول ساقهجه به رقم غريب و حداكثر

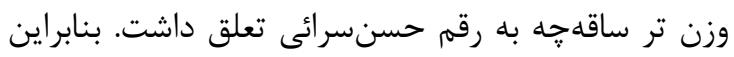
بلنظر مىرسد نتايج حاصله از سطوح شورى بالا در سطوح

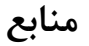

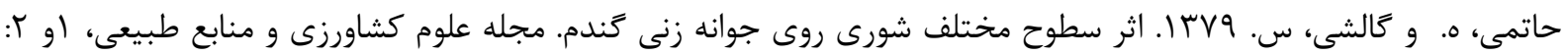

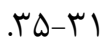
خالصرو، ش .و آقا عليخانى، م. عابـا. اثر تنش شورى و كم آبى بر جوانهزنى بذور سوركوم علوفه ایى و ارزن مرواريدى.

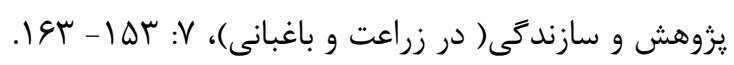

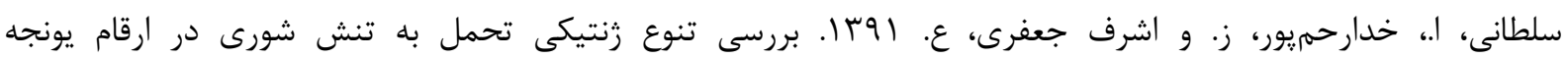
(Medicago sativa L.)

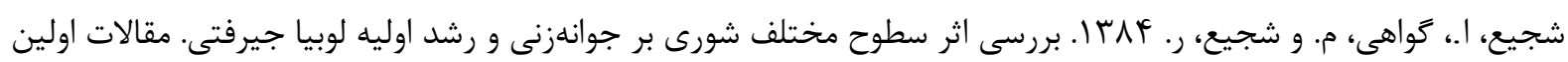

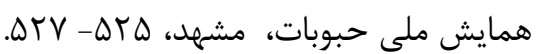

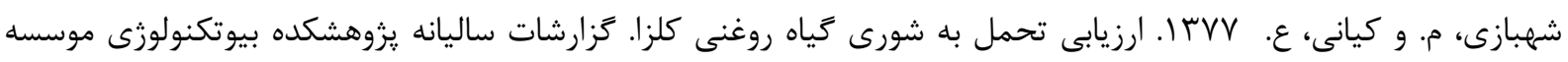
تحقيقات اصلاح وتهيه نهال و بذر.

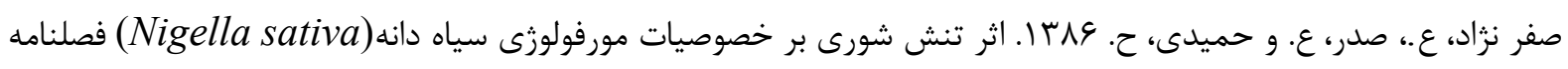

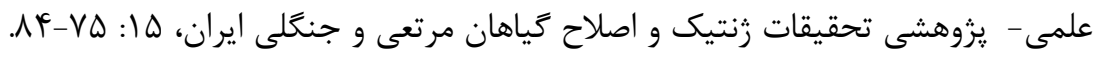

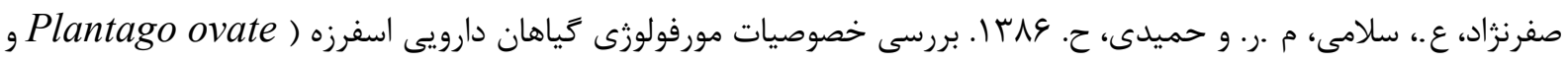

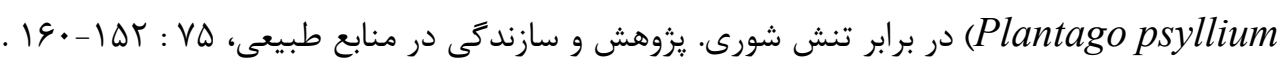

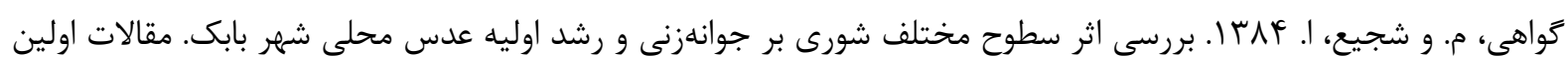

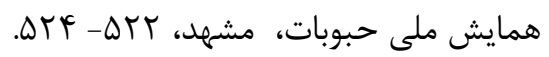

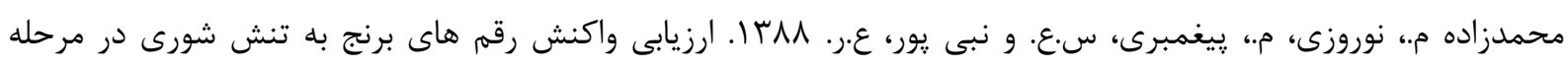

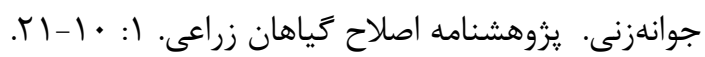

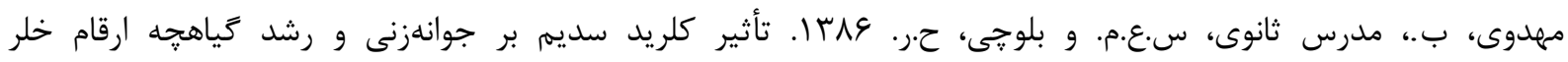
(Lathyrus sativus L.)

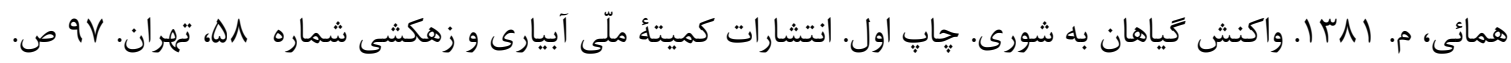

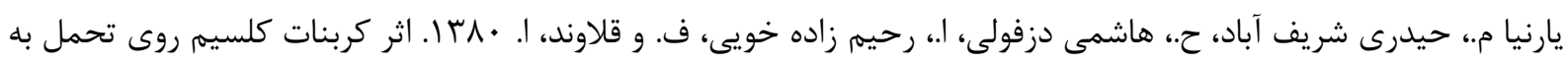

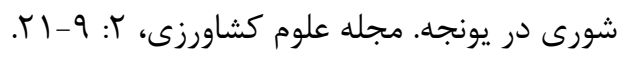

Akita, S., and Cabuslay, G.S. 1990. Physiological basic of different response to salinity in rice cultivars. Plant and Soil, 123: 227-249. 
Akram, M.S., Athar, H.R., and Ashraf, M. 2007. Improving growth and yield of sunflower (Helianthus annuus L.) by foliar application of potassium hydroxide $(\mathrm{KOH})$ under salt stress. Pakistan Journal of Botany, 39 (3):769-776.

Ansari, R., Shereen, A., Flowers, T.J., and Yeo, A.R. 2001. Identification rice lines for improved salt tolerance from a mapping population. In: Peng, S. and B. Hardy (eds.). Rice research for food security and poverty alleviation. Proceeding of the International Rice Research Conference, 31 March- 3 April 2000, Los Banos, Philippines. pp: 285-291.

Bybordi, A., and Tabatabaei, J. 2009. Effect of salinity stress on germination and seedling properties in canola cultivars (Brassica napus L.). Notula Botanicae Horti Agrobotanici Cluj-Napoca, 37 (2): 71-76.

Fougere, F., Rudulier, D.L., and Streeter, J.G. 1991. Effects of salt stress on amino acid, organic acid, and carbohydrate composition of roots bacteroids, and cytosol of alfalfa (Medicago sativa L.). Plant Physiology, 96(4): 1228-1236.

Janrdhan, R.P., and Vaid Yanaht, R. 1982. Note on the salt tolerance of some rice varieties of Andra prafesh during germination and early seedling growth. Indian Journal of Agriculture Science, 52(7): 472-474.

Karimi, N., Soheilikhah, Z., Ghasmpour, H.R., and Zebarjadi, A.R. 2011. Effect of salinity stress on germination and early seedling growth of different safflower (Carthamus tinctorius L.) genotypes. Journal of Ecobiotechnology, 3 (10): 07-13.

Kaya, M., and Ipek, D.A. 2003. Effects of different soil salinity levels on germination and seedling growth of safflower (Carthamus tinctorius L.). Turkish Journal of Agriculture and Forestry, 27(4): 221-227.

Khodarahmpour, Z. 2011. Screening maize (Zea mays L.) hybrids for salt stress tolerance at germination stage. African Journal of Biotechnology, 10 (71): 15959-15965.

Lang, N.T., Yanagihara, S., and Buu, B.C. 2001a. A microsatellite marker for a gene contributing salt tolerance on rice at the vegetative and reproductive stages. SABRAO Journal of Breeding and Genetics, 33: 1-10.

Lang, N.T., Yanagihara, S., and Buu, B.C. 2001b. QTL analysis of salt tolerance in rice (Oryza sativa L.). SABRAO Journal of Breeding and Genetics, 33: 11-20.

Mensuh, J.K., Akomeah, P.A., Ikhajiagbe, B., and Ekpekurede, E.O. 2006. Effects of salinity on germination, growth and yield of five groundnut genotypes. African Journal of Biotechnology, 5 (20): 1973-1979.

Mohammad, El.M., Benbella, M., and Talouizete, A. 2002. Effect of sodium chloride on sunflower (Helianthus annuus L.) seed germination. Helia Journal, 25 (37): 51-58.

Moradi, F. 2002. Physiological characterization of rice cultivars for salinity tolerance during vegetative and reproductive stages. Ph.D. thesis. University of Philippines, Los Banos. Philippines.

Mostafavi, K. 2011. An Evaluation of Safflower Genotypes (Carthamus tinctorius L.), Seed Germination and Seedling Characters in salt Stress Conditions. African Journal of Agricultral Research, 6 (7): 1667-1672.

Noor, E., Azhar, F.M., and Khan, A.L. 2001. Differences in responses of gossypium hirsutum L. varieties to $\mathrm{NaCl}$ salinity at seedling stage. International Journal of Agriulture Biology, 3 (4): 345-347.

Oksu, G., Kaya, M.D., and Atak, M.2005. Effects of salt and drought stresses on germination and seedling growth of pea (Pisum sativum L.). Turkish Journal of Agriculture and Forestry, 29(4): 237-242.

Shahid, M., Pervez, M.A., and Ashraf, M.Y. 2011. Characterization of salt tolerant and salt sensitive pea (Pisum sativum L.) genotypes under saline regime. Pakistan Journal of Life and Social Science, 9 (2):145-152. 
Tunçtürk, M., Tunçtürk, R., Yildirim, B., and Çiftçi, V. 2011. Changes of micronutrients, dry weight and plant development in canola (Brassica napus L.) cultivars under salt stress. African Journal of Biotechnology. 10 (19): 3726-3730.

Turhan, H., and Ayaz, C. 2004. Effect of salinity on seedling emergence and growth of sunflower (Helianthus annus L.) cultivars. International Journal of Agriculture and Biology, 6(1): 149-152.

Yildirim, E., and Guvenc, I. 2006. Salt tolerance of pepper cultivars during germination and seedling growth Turkish Journal of Agriculture and Forestry, 30(5): 347-353. 


\title{
The reaction of different cultivars of rice (Oryza sativa L.) to high and low salinity in vitro condition
}

\author{
Asad Masoumi Ast ${ }^{* 1}$, Reza Amiri Fahliani ${ }^{1}$, Hamidreza Balouchi ${ }^{2}$ \\ ${ }^{1}$ Assistant Professor, Department of Agronomy and Plant Breeding, Yasouj University \\ ${ }^{2}$ Associate Professor, Department of Agronomy and Plant Breeding, Yasouj University \\ *Corresponding Author E-mail: masumias1@yahoo.com
}

(Received: 2014/01/13 - Accepted: 2014/04/11)

\begin{abstract}
Salinity is one of the most extensive environment stresses and is a limiting factor for the growth and development of crops, such as rice. Then, an experiment based upon completely randomized design with four low levels $(0,7.5,15,22.5)$ and four high of salinity $(75,150$, 225 and $300 \mathrm{mM}$ ) with control as the first factor and nine cultivars of rice (dollars, Hasan Saraii, Mousa Tarom, Kamfiruz, Lenjan Askari, Gharib, Domsiah Mamassani, 304, Champa Yasouj) as the second factor with three replications was conducted in 2012 in the Yasouj University. Results showed that Hasan Saraii had salinity tolerance with the most germination percentage, germination rate and shoot length at high salinity levels (more than $75 \mathrm{mM}$ ), and Domsiah Mamassani with the minimum of that traits had not any salinity tolerance. But in the low salinity (less than $22.5 \mathrm{mM}$ ), Hasan Saraii, Lenjan and Mousa Tarom had the highest percentage of germination. The maximum germination rate was due to Mousa Tarom and the maximum shoot length observed in Gharib variety. So it seems, if we would only consider the germination percentage, Hasan Saraii is the best variety and if the maximum germination percentage and rate are considered, the variety that would be considered is Mousa Tarom. Therefore, high salinity we should not just rely on the germination; but the germination rate should also be noted and in lower salinity due to different cultivars germination percentage, germination rate and dry weight of root should be paid much more attention.
\end{abstract}

Keywords: Rice, Salinity, Germination Percentage, Germination Rate, Seed Vigor 